\title{
SCHOOL EFFECTIVENESS IN THE BAHAMAS
}

\section{Pandora Johnson (The College of The Bahamas) and Mark Holmes (Ontario Institute for Studies in Education)}

\begin{abstract}
Over the past two decades interest in student achievement and school improvement has resulted in an enhanced number of studies concerned with school effectiveness. These investigations have focussed largely on developed countries and have thrown into relief a set of characteristics deemed to be associated with high academic achievement, net of background factors; the most potent of which seems to be school climate. This article utilizes data drawn from an investigation carried out in an emerging society to examine the extent to which findings from highly industrialized countries are applicable in other countries with different social and economic characteristics. In particular it explores the relationship between school climate and school effectiveness and concludes that prevailing effectiveness ideas may be extrapolated to The Bahamas.
\end{abstract}

\section{SCHOOL EFFECTIVENESS}

The general findings concerning school effectiveness are among the best known in the educational literature. Over a period of about two decades, similar correlates of school effectiveness have been found in schools in Canada (e.g. Holmes 1971), in England (e.g. Rutter et al. 1979), as well as in the U.S.A. where Teddlie, Kirby and Stringfield (1989) completed a major study.

The criteria of effectiveness, virtually without exception, include or, more frequently, are limited to measures of academic success and, less frequently, include measures of behaviour and other manifestations of citizenship, e.g. regular attendance, absence of vandalism and graffiti. The independent variables, so called correlates of effectiveness, form a generally agreed upon list: school or academic climate, leadership, mission and school/ home relationships. School climate is probably the single best predictor of the effective school.

Within the term school climate are included such correlates as a pleasant and orderly atmosphere, regular monitoring of achievement and high academic expectations. It is usually operationalized in some of the following ways: academic work is considered important by students, teachers and administrators; both students and teachers have high academic expectations; good academic work is rewarded 
frequently; homework is assigned regularly and graded quickly; the school is well maintained in order to provide an environment that is inviting and pleasing; the school is safe and orderly.

Climate variables in most studies, including ours, usually measure accessible characteristics of schools which are at best proxy variables for the underlying characteristics of the effective school. For example, probably few people believe that beginning to set homework on a regular basis will in itself effect improvement. Nevertheless, it seems reasonable, conceptually and empirically, to assume that climate is a little closer to the heart of the matter (genuine school level effectiveness) than is a measure of leadership or of mission. Even if homework practice and policy are not of themselves sufficient to improve academic outcomes, they do form part of a conceptually coherent set of manipulable activities.

Our major focus, in the empirical section of the paper therefore, is on a measure of school climate. The data on which the analysis is based is drawn from a very large study, The Bahamas School Effectiveness Study. School climate is emphasized not because its origin lies only in the school, but because it is the most consistently reported variable (or set of variables) and one which is certainly manipulable.

\section{METHODOLOGY}

The Bahamas project is a conventional study of effectiveness with sets of background, intervening and dependent variables. The background variables are medsures of factors over which schools ean be said to have little influence; the intervening variables are measures derived from our definition of school climate. measure d by questionnaires to principals, teachers and students: and the dependent variables are measures of student success on GCE examinations. In all cases, the school is the unit of analysis.

All high schools in the Commonwealth of The Bahamas were invited to participate and 20 of the 36 schools agreed. Although participation in the project was therefore not random it was representative. Schools from all three geographical groupings, New Providence (Nassau), Grand Bahama (Freeport) and the Family Islands, participated. Of the 14 private schools, 8 participated; of the 22 public, 12 participated. Data which were collected in 1987 were derived from two separate samples of students, a sample of teachers and all principals. The numbers involved are shown in Table 1, p.36. 
For the purposes of the background variables and those intervening variables measured by means of student questionnaires, two classes of students were selected in each school after consultation with the principal: one from the graduating year and one from the first GCE year, roughly equivalent to an American tenth grade. One cannot be sure that the selected classes were representative of the population as a whole. For example, in larger schools any class not leading to GCE examinations was excluded. As Bahamian schools are generally not streamed, except insofar as some schools have non-GCE classes, it is unlikely that any class is very unrepresentative. Although all students in the selected classes completed the questionnaires, the analysis is based on random samples except in the case of Sands, where all students were selected, and in Trinity where only a senior class was made available in error.

The background variables are referred to as IQ and SES. IQ refers to the scores of the sampled students on the Otis-Lennon mental ability test administered for purposes of the project. SES refers to the occupational status of the family breadwinner, the father if available. Instead of using either the mean or median IQ and SES score, the 75th percentile was adopted. The rationale is that the British GCE (subsequently replaced in Britain by the more broadly applicable GCSE and in The Bahamas by the BGCSE) was never intended to serve the entire population. The 75th percentile was felt to be more representative of the portion of the population likely to be successful in GCE ' $\mathrm{O}^{\prime}$ level examinations. (Subsequently, we have recalculated the most important statistics using the median score with very much the same results, suggesting that the clasșes are normally distributed). So, while our background measures may not in some cases reflect the population of the school, they do reasonably represent students likely to take the GCE. The systematic exclusion of some classes in the larger schools should not advantage those schools. The use of the 75 th percentile effectively excludes the less academic students in all schools from the prediction of outcomes.

All sampled students also completed questionnaires with items related to various so called "correlates" of school effectiveness. Generally, the items found to be most strongly related to our measures of output, i.e. GCE results, are ones that we describe as being aspects of school climate. Our composite measure of school climate includes items from both the student and the teacher questionnaires.

The intent was to obtain completed questionnaires from a sample of $20 \%$ of the teachers in each school. The teachers were selected as cross-section by subject in an informal manner (the intent was a $20 \%$ sample). As Table 1 shows, not all teachers completed questionnaires, either because they did not in fact receive them through distribution error or because they chose not to. Despite the incomplete and in a few cases small returns, the teachers' responses were generally the best predictors of the outcomes, better than either the students' or the principals'. All the principals 
completed questionnaires, but their responses generally had little predictive power. The comparative utility of teachers' responses is not entirely typical of effective schools research, in which students' responses are often found more useful (McDill and Rigsby 1973; Holmes 1971).

Outcomes (the dependent variables) were not measured among the samples of students used for the independent variables, as this was not a longitudinal study. Instead, the GCE successes of the graduating classes of 1985 and 1986 were utilized, the most recent available. The GCE is the generally recognized educational credential in The Bahamas, as it is in many countries with a British tradition. It is a matter of debate within that British tradition as to whether it is more desirable to have broad participation and therefore widely based success, or whether it is more desirable to concentrate on the academic excellence of the few. For that reason, two statistics were calculated, one of academic breadth, the other of academic depth. Breadth is the total number of students with at least one credit in either of the two years as a proportion of the number of students in the two graduating classes. Depth is the total number of credits eamed in the two years as a proportion of the (same) total number of students. Our measure of achievement is a combination of breadth and depth. The breadth scores vary from 0.11 in Independence, a small Family Island school, to 0.69 in Kirklyn, the private school of highest prestige. The depth scores vary from 0.19 in Independence to 3.16 in Kirklyn, with 2.02 being the score of the second-ranking, (also private) school. The background and the achievement variables are shown in Table 2, pp.37-38. To equalize the contributions of breadth and depth, the two variables were converted to standard scores, shown in Table 3, pp.39-40. Six of the eight private schools are above the mean, nine of the twelve public below. As seven of the eight private schools are above the mean IQ, and all eight are above the mean SES, the disparity in achievement is hardly surprising. The coefficients of correlation between achievement and IQ and SES are 0.57 and 0.83 respectively. The relative strength of SES is noteworthy.

To obtain a measure of effectiveness, i.e. achievement net of IQ and SES, we regressed achievement on IQ and SES for each school and then calculated the mean of the two predicted quotients, to arrive at a predicted achievement level for each school, based on background factors. The effectiveness scores shown in Table 3 are the standardized forms of separate calculations for depth and breadth, where actual achievement is divided by predicted achievement. It will be noted that four of the eight private schools, four of the seven Family Island schools and one of the five urban schools are above the mean.

Our first purpose was to discover whether or not school climate contributes to an explanation of differing levels of effectiveness in Bahamian schools. Five variables were selected to form a composite measure of school climate on the basis of three 
criteria. The most important criterion was that the chosen variables should be strongly correlated with effectiveness; the second that there should be limited collinearity.

There are problems both ways. If one looks for collinearity one has the satisfaction of building a valid scale, but it is offset by limited validity: one is measuring only one aspect, however reliable it may be, of climate. If one selects variables that are not interrelated (if indeed such variables exist), then their composite conceptual meaning is suspect: one has put together a grab-bag of things whose meaning is undecipherable. We chose a compromise, with emphasis on validity and magnitude.

The other two criteria were that the variables should together make some conceptual sense of the idea of climate and they should be conceptually manipulable within the school. The five variables composing the climate variable come from two sources--the teachers' and the students' questionnaires. Ideally, the principal's questionnaire would also have been incorporated. The two student based variables are both concemed with homework, one with the regularity with which it is set, the other with the regularity and immediacy of its being marked. One of the teacher based variables is, consistently, concerned with regularity of the setting of homework, the other two with the incidence of problems of vandalism and skipping of classes.

The schools' relative standing on the climate variables is shown in Table 4, pp. $41-42$. The four private schools above the mean in effectiveness are all above the mean in climate. Of the five more effective public schools, four are above the mean in climate. Table 5, p.43, shows the relationships among the components of the climate variable. The correlation coefficients measuring the relationships between climate, the composite variable, and the components vary between 0.76 and 0.41 , while the coefficients among the components are much more variable, from -0.38 to 0.78 . Overall, there is moderate collinearity.

\section{SCHOOL EFFECTIVENESS IN THE BAHAMAS}

As Table 6, p. 44 shows, the school effectiveness findings one would predict from American, British, and Canadian research apply similarly in The Bahamas. The relationship between climate and effectiveness is about that which one typically finds in other developed countries--0.619. It should be noted that the schools in this sample are more than usually heterogeneous. It is likely that significant findings are easier to achieve when the range of schools is great. But it must be bome in mind that a control of students' background is built into the effectiveness measure, which is the difference between actual achievement and the achievement predicted from background factors. 
Despite that, there remain small positive relationships between IQ and SES, the background factors, and effectiveness. There are several possible explanations. First, we may not have adequately controlled the background factors in our measure of effectiveness. However, it should be recalled that half the private schools (which are generally of high SES) are below average effectiveness. Another possibility is that there is a contextual effect of high social status composition. Previous research has been inconsistent on this question. It does seem likely that the highly varied schools of The Bahamas would vary in their social context and therefore possible that there would be some contextual influence over and above the influence of the family on the individual student.

Despite the lingering influence of the background variables, the comparative robustness of our measure of climate should not be overlooked. It is more strongly correlated with effectiveness (and its two components) than is either of the background measures. When effectiveness is regressed on the three independent variables ( $R 2$ is 0.432 ), only climate is statistically significant $(p=<0.013)$. It could be argued from a perspective of equity, that breadth is a better indicator of effectiveness than depth; presumably the more affluent schools are more able to provide a wide range of subject specia lizations, thereby contributing to depth. Climate is slightly more related to breadth $(r=0.619)$ than to depth $(r=0.494)$. When breadth is regressed on IQ, SES and climate, only climate's beta coefficient is statistically significant $(p=<0.009)$. It is clear that climate, as operationalized, is an important correlate of school effectiveness in The Bahamas. Those schools, public and private, which are able to provide an academic emphasis within a safe and orderly context are more successful in GCE examination than are schools without such contexts.

\section{DISCUSSION}

We have looked at the idea of school effectiveness in the context of The Commonwealth of The Bahamas. Overall, the findings are suggestive rather than conclusive, as they are based on a number of assumptions that can be reasonably challenged. The data also raise questions which can only be answered speculatively.

We have assumed that the background measures of IQ and SES are reasonable proxies of the realities that make Bahamian children different: culturally and intellectually. The assumption is supported by the strong relationships between those variables and measures of student achievement. Nevertheless, if they substantially under explain the naturally occurring differences, it is possible that our measure of climate has mistakenly picked up some of that remaining background variance. As neither SES nor IQ significantly explains effectiveness when placed in a regression equation with climate, that seems improbable. So, we believe that some confidence 
can be placed in the finding that beliefs about school life and practices, i.e. the incidence of the setting and checking of homework, of vandalism and of skipping school, are related to the achievement of the school when background variables are controlled. This finding is consistent with virtually all effectiveness studies in the developed, English speaking world.

\section{CONCLUSION}

If one simply looks at the overall data on backgtound, school climate and academic effectiveness, The Bahamas is very similar to other developed Englishspeaking societies. IQ and SES are strongly related to school success, private schools are more successful than public schools, and school climate is a good predictor of effectiveness, net of background factors. There is a little evidence. supporting the influence of contextual social status--children seem to perform better, leaving aside their own background characteristics, in high SES schools than on low SES schools. Academic breadth, measuring the numbers of students having some success, seems to be more sensitive to differences among the public schools than does academic depth; a measure of the amount of success, although the latter variable shows the greater distinction among all schools. More simply some public schools, Southern and Sands, provide some GCE success to a high proportion of their students but some private schools, Kirklyn and St. Hilda's, are particularly successful in providing some of their students a wide range of GCE successes.

The lack of success of the large urban, public high school is again confirmed. Generally low on both climate and effectiveness, these schools show how difficult is the task of administering the urban secondary school in developed societies in the English speaking western world. The most successful schools in The Bahamas are either not public and not low SES, or not urban.

In this study, not a single urban public school was above average on climate. In Holmes' New Jersey report, he notes that over $60 \%$ of the achievement variance in that state's high schools can be explained by crude measures of race and poverty (Holmes 1990a). We do not wish to discount the likelihood that school administrators and staff can influence academic climate and, thereby, effectiveness. That influence is probably very much subject to the local ecology; it is simply not at all easy, perhaps not possible to turn around the disaffected large, comprehensive high school.

As private schools can still be successful and favoured even when attended by quite high proportions of the population, it seems sensible to advocate the cautious development of choice, accompanied by school specialization and, wherever financially feasible, by downsizing. Small schools are more flexible in the sense that their success or failure is less of a shock to the entire system. 
TABLE 1

ENROLLMENT AND SAMPLES

\begin{tabular}{|c|c|c|c|c|}
\hline Schools & Fonollment & $\begin{array}{l}\text { Achieve- } \\
\text { ment }\end{array}$ & $\begin{array}{l}\text { Background } \& \\
\text { Climate }\end{array}$ & Teachers \\
\hline $\begin{array}{l}\text { Private } \\
\text { 1. Kirklyn } \\
\text { 2. St. Hildla's } \\
\text { 3. St. Burton's } \\
\text { 4. Weslyn } \\
\text { 5. St. Michael } \\
\text { 6. Christian } \\
\text { 7. Trinity } \\
\text { 8. Temple }\end{array}$ & $\begin{array}{l}317 \\
395 \\
586 \\
654 \\
389 \\
292 \\
3.38 \\
364\end{array}$ & $\begin{array}{l}100 \\
164 \\
196 \\
240 \\
181 \\
68 \\
1.33 \\
1.59\end{array}$ & $\begin{array}{l}35 \\
45 \\
40 \\
37 \\
44 \\
36 \\
23 \\
31\end{array}$ & $\begin{array}{c}8 \\
8 \\
11 \\
14 \\
7 \\
3 \\
7 \\
5\end{array}$ \\
\hline $\begin{array}{l}\text { Family--fishing } \\
\text { 9. Sands } \\
\text { 10. Freetown } \\
\text { 11. Independence } \\
\text { 12. Baintown }\end{array}$ & $\begin{array}{l}192 \\
249 \\
249 \\
1.31\end{array}$ & $\begin{array}{l}11 \\
51 \\
47 \\
14\end{array}$ & $\begin{array}{l}11 \\
30 \\
39 \\
25\end{array}$ & $\begin{array}{l}4 \\
4 \\
5 \\
8\end{array}$ \\
\hline $\begin{array}{l}\text { Family-farming } \\
\text { 13. Southem } \\
\text { 14. Central } \\
\text { 15. Norand }\end{array}$ & $\begin{array}{l}307 \\
32 ! \\
398\end{array}$ & $\begin{array}{l}62 \\
73 \\
80\end{array}$ & $\begin{array}{l}34 \\
27 \\
42\end{array}$ & $\begin{array}{c}6 \\
11 \\
8\end{array}$ \\
\hline $\begin{array}{l}\text { Urban } \\
\text { 16. Bahama } \\
\text { 17. Highland } \\
\text { 18. Westem } \\
\text { 19. Eastem } \\
\text { 20. Northern }\end{array}$ & $\begin{array}{l}1061 \\
15.34 \\
1639 \\
968 \\
17.32\end{array}$ & $\begin{array}{c}77 \\
353 \\
429 \\
52 \\
167\end{array}$ & $\begin{array}{l}39 \\
44 \\
35 \\
33 \\
44\end{array}$ & $\begin{array}{c}12 \\
11 \\
8 \\
8 \\
10\end{array}$ \\
\hline
\end{tabular}

\section{Notes}

Achievement

Background \& Climate

'Teachers
The $N$ of the graduating classes of 1985 and 1986.

The $\mathrm{N}$ of the simple of students used for the generation of the independent variables, i.e. SES, IQ and climate.

The $\mathrm{N}$ of the tachers completing questionnaires. 
TABLE 2

BACKGROUND AND ACHIEVEMENT--RAW DATA

\begin{tabular}{|c|c|c|c|c|}
\hline SCHOOLS & IQ & SES & DEPTH & BREADTH \\
\hline $\begin{array}{l}\text { Private } \\
\text { 1. Kirklyn } \\
\text { 2. St. Hilda's } \\
\text { 3. St. Burton's } \\
\text { 4. Weslyn } \\
\text { 5. St. Michael's } \\
\text { 6. Christian } \\
\text { 7. Trinity } \\
\text { 8. Temple }\end{array}$ & $\begin{array}{l}110 \\
112 \\
106 \\
111 \\
116 \\
118 \\
103 \\
102\end{array}$ & $\begin{array}{r}10.0 \\
8.0 \\
10.0 \\
10.0 \\
8.0 \\
8.0 \\
8.0 \\
8.0\end{array}$ & $\begin{array}{l}3.16 \\
1.90 \\
2.02 \\
1.93 \\
1.19 \\
.99 \\
.76 \\
.37\end{array}$ & $\begin{array}{l}.69 \\
.64 \\
.68 \\
.66 \\
.53 \\
.59 \\
.46 \\
.25\end{array}$ \\
\hline $\begin{array}{l}\text { Family--fishing } \\
\text { 9. Sands } \\
\text { 10. Freetown } \\
\text { 11. Independence } \\
\text { 12. Baintown }\end{array}$ & $\begin{array}{c}104 \\
97 \\
86 \\
100\end{array}$ & $\begin{array}{l}6.8 \\
6.5 \\
6.3 \\
7.3\end{array}$ & $\begin{array}{l}1.00 \\
.35 \\
.19 \\
.29\end{array}$ & $\begin{array}{l}.55 \\
.24 \\
.11 \\
.29\end{array}$ \\
\hline $\begin{array}{l}\text { Family--farming } \\
\text { 13. Southem } \\
\text { 14. Central } \\
\text { 15. Norand }\end{array}$ & $\begin{array}{l}90 \\
93 \\
98\end{array}$ & $\begin{array}{l}8.0 \\
6.0 \\
6.3\end{array}$ & $\begin{array}{l}1.23 \\
.62 \\
.48\end{array}$ & $\begin{array}{l}.58 \\
.38 \\
.43\end{array}$ \\
\hline $\begin{array}{l}\text { Urban } \\
\text { 16. Bahama } \\
\text { 17. Highland } \\
\text { 18. Western } \\
\text { 19. Eastem } \\
\text { 20. Northem }\end{array}$ & $\begin{array}{c}96 \\
98 \\
111 \\
92 \\
114\end{array}$ & $\begin{array}{l}6.0 \\
7.0 \\
8.0 \\
6.3 \\
8.0\end{array}$ & $\begin{array}{l}.42 \\
.67 \\
1.02 \\
.21 \\
.72\end{array}$ & $\begin{array}{l}.34 \\
.38 \\
.48 \\
.13 \\
.43\end{array}$ \\
\hline Mean & 103 & 7.7 & .98 & .44 \\
\hline SD & 9 & 1.3 & .76 & .18 \\
\hline
\end{tabular}


Notes

IQ

The 75th percentile of sampled students on the Otis Lennon test of mental aptitude.

SES

The 75th percentile of quantified transcriptions of the occupation of the principal breadwinner.

Depth The total number of GCE passes achieved by the graduating classes in 1985 and 1986 as a fraction of the graduating classes; i.e. Kirklyn students attained just over 3 GCEs per person, while in Eastem there was slightly over 1 GCE success for every 5 students.

Breadth The total number of students with at least 1 GCE pass in 1985 and 1986 as a fraction of all graduates; i.e. $69 \%$ of Kirklyn students achieved at least one GCE pass, while $11 \%$ of Independence students were as successful. 
TABLE 3

ACHIEVEMENT (DEPTH AND BREADTH)

AND EFFECTIVENESS (DEPTH AND BREADTH)

IN STANDARD SCORES

\begin{tabular}{|l|l|l|l|l|l|l||}
\hline SCHOOLS & Dep $\Lambda$ & Brea $\Lambda$ & Achieve & Dep F & Brea E & $\begin{array}{l}\text { Effec- } \\
\text { tive }\end{array}$ \\
\hline Private & & & & & & \\
1. Kirklyn & 79 & 64 & 143 & 80 & 57 & 137 \\
2. St. Hilda's & 62 & 61 & 123 & 63 & 61 & 124 \\
3. St. Burton's & 64 & 63 & 127 & 58 & 58 & 116 \\
4. Weslyn & 63 & 62 & 125 & 54 & 54 & 108 \\
5. St. Michael & 53 & 55 & 108 & 46 & 48 & 94 \\
6. Christian & 50 & 58 & 108 & 41 & 53 & 94 \\
7. Trinity & 47 & 51 & 98 & 43 & 50 & 93 \\
8. Temple & 42 & 39 & 81 & 36 & 31 & 67 \\
\hline Family--fish & & & & & & \\
9. Sands & 50 & 56 & 106 & 54 & 63 & 117 \\
10. Freetown & 42 & 39 & 81 & 45 & 40 & 85 \\
11. Independence40 & 32 & 72 & 48 & 35 & 83 & - \\
12. Baintown & 41 & 42 & 83 & 42 & 39 & 81 \\
\hline Family-farm & & & & & & \\
13. Southem & 53 & 58 & 111 & 59 & 68 & 127 \\
14. Central & 45 & 47 & 92 & 55 & 57 & 112 \\
15. Norand & 43 & 49 & 92 & 49 & 57 & 106 \\
\hline Urban & & & & & & \\
16. Bahama & 40 & 50 & 100 & 50 & 50 & 100 \\
17. Highland & 43 & 44 & 87 & 50 & 53 & 103 \\
18. Westem & 46 & 47 & 93 & 49 & 50 & 99 \\
19. Eastem & 51 & 52 & 103 & 45 & 46 & 91 \\
20. Northem & 40 & 33 & 73 & 46 & 34 & 80 \\
\hline Mean & 47 & 49 & 96 & 37 & 41 & 78 \\
\hline SD & 50 & 10 & 19.6 & 10 & 10 & 18.3 \\
\hline
\end{tabular}


Notes

Dep A Depth GCE scores transformed to standard scores.

Brea A Breadth GCE scores transformed to standard scores.

Achieve Sum of depth and breadth: achievernent.

Dep E Predicted depth scores (from background) less actual depth scores transformed to standard scores; effectiveness.

Brea E Predicted breadth scores less actual breadth scores transformed to standard scores; effectiveness.

Effect Sum of Dep $\mathbf{E}$ and Brea $\mathbf{E}$ transformed to standard scores;

effectiveness. This measure of effectiveness gives equal weight to depth and breadth. 
TABLE 4

SCHOOL CLIMATE IN STANDARD SCORES

\begin{tabular}{|c|c|c|c|c|c|c|c|c|c|}
\hline SCHOOL & HW A & $\mathrm{HW} C$ & CLS & VAND & SKIP & HW $T$ & $\mathrm{CLT}$ & CL & $\mathrm{EEF}$ \\
\hline $\begin{array}{l}\text { 1. Kir } \\
\text { 2. St. H } \\
\text { 3. St. B } \\
\text { 4. } \text { Wes } \\
\text { 5. St. M } \\
\text { 6. Chr } \\
\text { 7. Tri } \\
\text { 8. Tem } \\
\text { Mean }\end{array}$ & $\begin{array}{l}57 \\
55 \\
55 \\
52 \\
29 \\
58 \\
51 \\
36 \\
49\end{array}$ & $\begin{array}{l}51 \\
66 \\
47 \\
63 \\
25 \\
60 \\
40 \\
45 \\
50\end{array}$ & $\begin{array}{l}54 \\
61 \\
51 \\
58 \\
27 \\
59 \\
46 \\
41 \\
50\end{array}$ & $\begin{array}{l}54 \\
56 \\
60 \\
46 \\
75 \\
50 \\
47 \\
47 \\
54\end{array}$ & $\begin{array}{l}60 \\
58 \\
47 \\
54 \\
69 \\
56 \\
52 \\
51 \\
56\end{array}$ & $\begin{array}{l}50 \\
64 \\
59 \\
53 \\
59 \\
66 \\
53 \\
49 \\
56\end{array}$ & $\begin{array}{l}55 \\
59 \\
55 \\
51 \\
68 \\
57 \\
51 \\
49 \\
56\end{array}$ & $\begin{array}{l}54 \\
60 \\
53 \\
55 \\
47 \\
58 \\
48 \\
45 \\
53\end{array}$ & $\begin{array}{r}137 \\
124 \\
116 \\
108 \\
94 \\
94 \\
93 \\
67 \\
104\end{array}$ \\
\hline 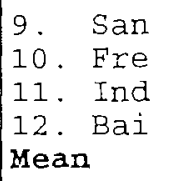 & $\begin{array}{l}55 \\
55 \\
36 \\
50 \\
49\end{array}$ & $\begin{array}{l}36 \\
43 \\
45 \\
55 \\
45\end{array}$ & $\begin{array}{l}46 \\
49 \\
41 \\
53 \\
47\end{array}$ & $\begin{array}{l}61 \\
42 \\
46 \\
60 \\
52\end{array}$ & $\begin{array}{l}53 \\
50 \\
44 \\
62 \\
52\end{array}$ & $\begin{array}{l}56 \\
56 \\
41 \\
50 \\
51\end{array}$ & $\begin{array}{l}57 \\
49 \\
44 \\
57 \\
52\end{array}$ & $\begin{array}{l}51 \\
49 \\
42 \\
55 \\
49\end{array}$ & $\begin{array}{r}117 \\
85 \\
83 \\
81 \\
92\end{array}$ \\
\hline $\begin{array}{ll}\text { 13. } & \text { Sou } \\
14 . & \text { Cen } \\
15 . & \text { Nor } \\
\text { Mean. }\end{array}$ & $\begin{array}{l}60 \\
54 \\
55 \\
56\end{array}$ & $\begin{array}{l}53 \\
47 \\
51 \\
50\end{array}$ & $\begin{array}{l}57 \\
51 \\
53 \\
53\end{array}$ & $\begin{array}{l}55 \\
54 \\
54 \\
54\end{array}$ & $\begin{array}{l}59 \\
54 \\
48 \\
54\end{array}$ & $\begin{array}{l}59 \\
51 \\
45 \\
52\end{array}$ & $\begin{array}{l}58 \\
53 \\
51 \\
54\end{array}$ & $\begin{array}{l}57 \\
52 \\
52 \\
54\end{array}$ & $\begin{array}{l}127 \\
112 \\
106 \\
112\end{array}$ \\
\hline $\begin{array}{l}\text { 16. Bah } \\
17 . \text { Hig } \\
18 . \text { Wst } \\
19 . \text { Est } \\
\text { 20. Nth } \\
\text { Mean }\end{array}$ & $\begin{array}{l}26 \\
57 \\
57 \\
49 \\
53 \\
43\end{array}$ & $\begin{array}{l}62 \\
52 \\
55 \\
58 \\
43 \\
54\end{array}$ & $\begin{array}{l}44 \\
55 \\
56 \\
54 \\
48 \\
51\end{array}$ & $\begin{array}{l}42 \\
35 \\
38 \\
40 \\
34 \\
38\end{array}$ & $\begin{array}{l}41 \\
34 \\
44 \\
30 \\
35 \\
37\end{array}$ & $\begin{array}{l}41 \\
32 \\
40 \\
40 \\
32 \\
37\end{array}$ & $\begin{array}{l}41 \\
34 \\
41 \\
37 \\
34 \\
40\end{array}$ & $\begin{array}{l}43 \\
45 \\
49 \\
46 \\
41 \\
45\end{array}$ & $\begin{array}{r}103 \\
99 \\
91 \\
80 \\
78 \\
90\end{array}$ \\
\hline mean & 50 & 50 & 50 & 50 & 50 & 50 & 50 & 50 & 99.8 \\
\hline SD 10 & 10 & - & 10 & 10 & 10 & - & 5.5 & - & - \\
\hline
\end{tabular}


Notes

HW $\Lambda$ Regularity of assignment of homework in the opinion of students.

HW C Regularity of checking of homework in the opinion of students.

CLS Mean of HW A and HW C.

VAND Low incidence of vandalism in the opinion of teachers.

SKIP Low incidence of skipping of classes in the opinion of teachers.

HW T Regularity of setting of homework in the opinion of teachers.

CLT Mean of VAND, SKIP and HW T.

Cl Mean of $\mathrm{CL} \mathrm{S}$ and CL T--School climate.

EFF Effectiveness, based in standard scores: 
TABLE 5

CORRELATION MATRIX: CLIMATE

\begin{tabular}{|l|l|l|l|l|l|l|l|l||}
\hline & HW A & HW C & CLS & SKIP & HW T & HL T & CL & VAND \\
\hline HW A & 1.0 & - & - & - & - & - & - & - \\
\hline HW C & .257 & 1.0 & - & - & - & - & - & - \\
\hline CLS & .791 & .794 & 1.0 & - & - & - & - & - \\
\hline SKIP & -.015 & -.215 & -.145 & 1.0 & - & - & - & - \\
\hline HMT & .167 & -.035 & .083 & .776 & 1.0 & - & - & - \\
\hline CLT & .01 & -.248 & -.15 & .941 & .884 & 1.0 & - & - \\
\hline CL & .58 & .412 & .626 & .632 & .759 & .676 & 1.0 & - \\
\hline VAND & -.138 & -.384 & -.328 & .815 & .696 & .922 & .483 & 1.0 \\
\hline
\end{tabular}

Notes

HW A Regularity of assignment of homework in the opinion of students.

HW C Regularity of checking of homework in the opinion. of students.

CLS Mean of HW A and HW C.

VAND Low incidence of vandalism in the opinion of teachers.

SKIP Low incidence of skipping of classes in the opinion of teachers.

HW T Regularity of Setting of homework in the opinion of teachers.

CLT Mean of VAND, SKIP and HW T.

CL Mean of CL S and CL T - School climate.

EFF Effectiveness, based on non-standardized mores. 
TABLE 6

BACKGROUND, CLIMATE AND EFFECTIVENESS:

CORRELATION MATRIX

\begin{tabular}{|l|l|l|l|l|l|l|l||}
\hline & IQ & SES & Climatc & Achieve & Depth & Breadth & $\begin{array}{l}\text { Effec- } \\
\text { tive }\end{array}$ \\
\hline IQ & 1.0 & - & - & - & - & - & - \\
\hline SES & .626 & 1.0 & - & - & - & - & - \\
\hline Climate & .283 & .402 & 1.0 & - & - & - & - \\
\hline Achieve & .618 & .82 & .615 & 1.0 & - & - & - \\
\hline Depth & .003 & .39 & .494 & .717 & 1.0 & - & - \\
\hline Breadth & .159 & .256 & .63 & .7 & .656 & 1.0 & - \\
\hline $\begin{array}{l}\text { Effec- } \\
\text { tive }\end{array}$ & .091 & .354 & .619 & .779 & .907 & .912 & 1.0 \\
\hline
\end{tabular}

Notes

IQ $\quad$ Measured ability of students--background variable.

SES Occupation of family breadwinner--background variable.

Climate Score on climate measure--intervening vatiable.

Achievement Level of achievement (including depth and breadth).

Depth Effectiveness expressed as GCE passes per student, predicted achievement divided by actual achievement.

Breadth Effectiveness expressed as students with GCE passes as a proportion of all students, predicted achievement divided by actual achievement.

Effective Effectiveness expressed as sum of depth and breadth equally weighted. 


\section{REFERENCES}

1. BARLOVSKY, Martin. (1990) "Cultural Coherence in a Progtessive Altemative School". Unpublished paper, OISE, Toronto.

2. COLEMAN, James S. (1961) The Adolescent Society. New York:Free Press.

3. COLEMAN, James S., et al. (1966) Equality of Educational Opportunity. Washington:U.S. Government Printing Office.

4. COLEMAn, James S. and Hoffer, Thomas. (1987) Public and Private High Schools. New York:Basic Books.

5. COLEMAN, James S., Hoffer, Thomas, \& Kilgore, Sally. (1982) High School Achievement. New York.

6. HALlingeR, Philip \& Murphy, Joseph F. (May 1986) "The Social Context of Effective Schools". American Journal of Education, 94. pp.328-355.

7. HOLMES, Mark. (1971) "A Critique of Neo-Progressive Trends in Canadian Education". Interchange, 2 pp. 63-80.

8. HOLMES, Mark (1985) "The Funding of Private Schools in Ontario: Philosophy, Values and Implications for Funding". .In The Report of the Commission on Private Schools in Ontario, by Bernard J. Shapiro. The Commission on Private Schools in Ontario, Toronto.

9. HOLMES, Mark. (1985) "Organizational Climate in Schools". In International Encyclopedia of Education: Research and Studies, edited by Torsten Husen and Neville Postlethwaite. Oxford:Pergamon Press.

10. HOLMES, Mark (1988) "The Fortress Monastery: The Future of the Common Core". In Cultural Literacy and the Idea of General Education, edited by Alan C. Purves and Ian Westbury. Chicago:University of Chicago Press.

11. HOLMES, Mark. (1989) "School Effectiveness: From Research to Implementation to Improvement". In Educational Policy for Effective Schools, edited by Mark Holmes, Kenneth A. Leithwood, and Donald F. Musella. New York:Teachers College Press. 
12. HOLMES, Mark (1990a) "Effective Demonstration Schools Grant Program-New Jersey State Department of Education. Report of the External Evaluator". Unpublished report, OISE, Toronto.

13. HOLMES, Mark (1990b) "The Funding of Independent Schools". In Canadian Public Education System: Issues and Prospects, edited by Y.L. Lam. Edmonton, Alberta:De tselig.

14. JOHNSON, Pandora. (1988) "Effective Secondary Schooling: Factors Affecting Academic Achievement in The Commonwealth of The Bahamas". Unpublished Ph.D. dissertation, OISE, Toronto.

15. HUBERMAN, A.M. \& Miles, Matthew B. (1984) Innovation Up Close: How School Improvement Works. New York:Plenum Press.

16. McDILL, Edward L. \& Rigsby, Leo C. (1973) Structure and Process in Secondary Schools: The Academic Impact of Educational Climate. Baltimore:The Johns Hopkins University Press.

17. PESHKIN, Alan. (1986) God's Choice. Chicago:University of Chicago Press.

18. PURKEY, S., \& Smith, M. (March 1983) "Effective Schooling: A Review". Elementary School Journal,83. pp.427-452.

19. RUTTER, Michael, Maughan, Barbara, Mortimore, Peter, \& Ouston, Janet. (1979) Fifteen Thousand Hours. London:Open Books.

20. STRINGFIELD, Sam \& Teddlie, Charles (September 1989) "Ethics and the Administrator: Implications of Research on Effective Schools (2)". Ethics in Education. pp. 8-10.

21. TEDDLIE, Charles, Kirby, Peggy C., \& Stringfield, Sam. (1989) "Effective versus Ineffective Schools". American Journal of Education,97,3. pp. 221-236. 


\section{AUTHORS}

Mark Holmes, formerly of the Department of Educational Administration, Ontario Institute for Studies in Education (OISE), is one of the best known researchers in the field of School Effectiveness. The author of a number of books on the subject, he recently retired and now resides in New Brunswick, Canada.

Pandora Johnson is currently the Director of Research at The College of The Bahamas (COB). A lecturer in the Teacher Education Division for a number of years, her research interest parallels that of Mark Holmes. 